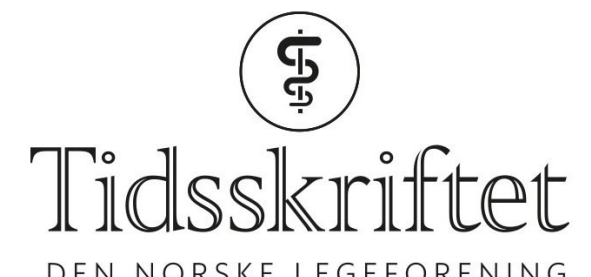

DEN NORSKE LEGEFORENING

\title{
En kronikørs bekjennelser
}

INTERVJU

CHRISTINA SVANSTRØM

E-post: christina@svanstrom.no

Det handler om nattesøvn, tankekjør og kunnskapsformidling. Derfor tar gynekolog Agnethe Lund høyt og tydelig ordet i den offentlige debatten.

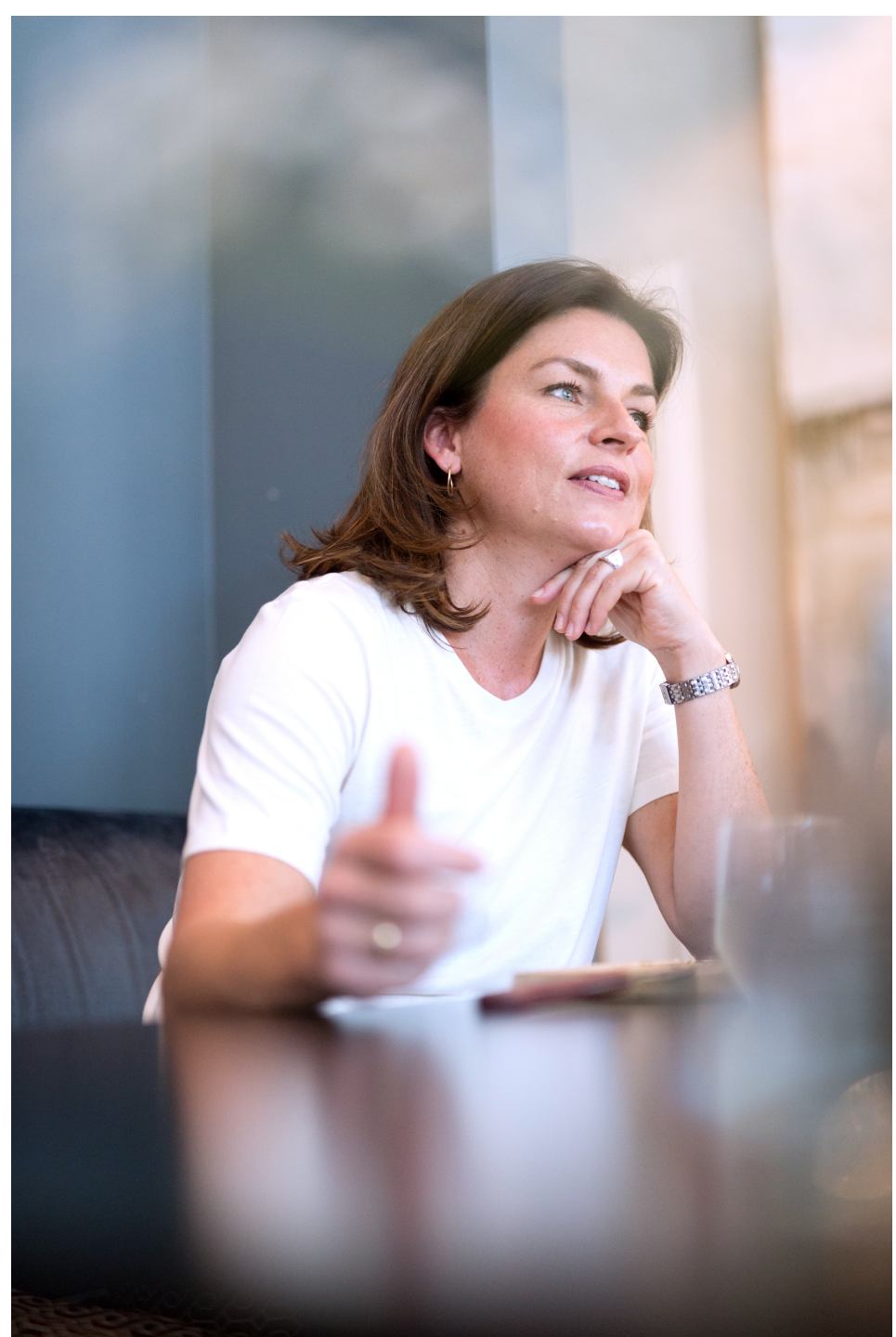

Alle foto: Magne Sandnes

Det tok flere år med en følelse av å bli urettferdig beskrevet før Agnethe Lund fant veien til 
tastaturet. Det startet med en tanke, så et argument. Små kronikker formet seg på innsiden.

- Første gangen jeg skrev en kronikk i Bergens Tidende var jeg egentlig veldig redd for at jeg skulle bli et hatobjekt i Bergen. Det var skrevet mye negativt om vår klinikk. Mye viktig og alvorlig. Men saker om våre gode tall uteble. Til slutt følte jeg at jeg måtte si noe om at vi bryr oss og at det egentlig ikke går så dårlig.

Opparbeidede argumenter måtte settes på papiret. Resultatet ble «Min faglige arroganse», som kom på trykk i 2012. Lund tar ærlig tak i hvorfor hun som fagperson fraråder keisersnitt der det ikke er nødvendig, men at hun forstår at den fødende kan oppleve det annerledes.

- Jeg var bevisst på å finne tonen jeg har i møte med en pasient som er skeptisk og mangler tillit, å prøve å vise en varme og at jeg bryr meg. Det er synd hvis vi fagfolk sitter på lukkede rom og rister på hodet over den offentlige debatten. Vi er nødt til å prøve å forklare det hvis vi mener en debatt har båret galt av sted. Og vi må la oss korrigere. Fremstår vi som arrogante, kan det hende det er riktig.

\section{Friske pasienter}

Det er en helt vanlig hverdag på Møllendal Fetevare i Bergen. Klientellet på kafeen består av både store og veldig små. En baby gråter et øyeblikk, før mammaen lener seg mot og dekker behovet. Det er mulig dagens møte med en fødselslege preger blikket. Men sammenlignet med Bergen sentrum er det påfallende større tetthet av barnevogner her, ikke så langt fra Kvinneklinikken.

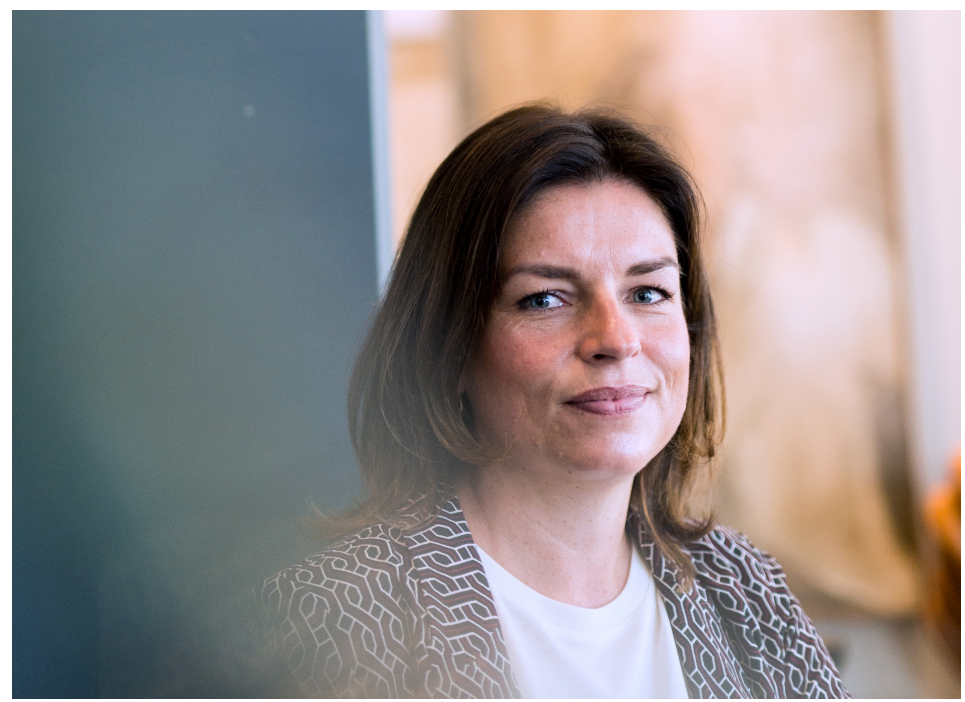

Det er én av de få ikke-regndagene i Bergen, og Lund kom syklende for å møte oss før jobb med sykkelhjelm, mønstret dress og hvit t-skjorte.

I dag er hun overlege. Men da hun for 14 år siden troppet opp på Kvinneklinikken for første gang, var det mange overraskelser i vente. Mye nytt, mye som kunne gå galt, store konsekvenser.

\section{Agnethe Lund}

Født 1972 i Bergen

Gift, to barn

Cand.med, Universitetet i Bergen 2001

Turnustjeneste, Harstad sykehus 2002-03

Kvinneklinikken i Bergen siden 2004

Ph.d.-stipendiat, Helse Vest og Universitetet i Bergen

Leder av innovasjonsprosjektet Dina chatbot

Årets debattant i Bergens Tidende 2015 
- Som turnuslege møtte jeg mange syke eldre. Men på Kvinneklinikken er de fleste akuttpasientene unge, friske gravide som skal fortsette å være friske - og få et friskt levende barn. Jeg er utrolig glad for at jeg ble gynekolog, men det var en tøff start før brikkene falt på plass.

- Er dette noe du er bevisst i møtet med yngre leger?

- Som overlege på et universitetssykehus jobber jeg med undervisning hele tiden. Jeg er sjelden i en situasjon uten student eller yngre lege i utdanning. Jeg forsøker å være empatisk, men pleier også å si at de bør tenke seg godt om før de blir gynekolog.

- Hvorfor det?

- Jeg er 46 år og går fortsatt tilstedevakt på sykehuset. Det er mye nattarbeid, våkenhet og tøffe operasjoner. Det er få andre jeg gikk på kull med som fortsatt har den typen vakter, sier Lund.

Selv om vaktbelastningen tar på, har Lund også funnet uventede lyspunkter i jobben etter hvert som årene har gått.

- Det å komme i kontakt med pasienter og å kjenne en genuin varme og glede over dialogen, det er noe jeg er takknemlig for å få oppleve i min jobb. Det er virkelig givende, på et emosjonelt plan. Emosjonelle ressurser må vi dyrke og ivareta - også i helsevesenet.

\section{Verdien av engasjementet}

Agnethe Lund beskrives av venner som modig og klar. En som tør å ta ordet når det trengs. Engasjementet for arbeidsvilkår og rettferdig ressursfordeling går som en brennende rød tråd gjennom det hun har fått på trykk: viktigheten av kompetanse i det offentlige sykehuset, og verdien av legenes glød for eget fag. 


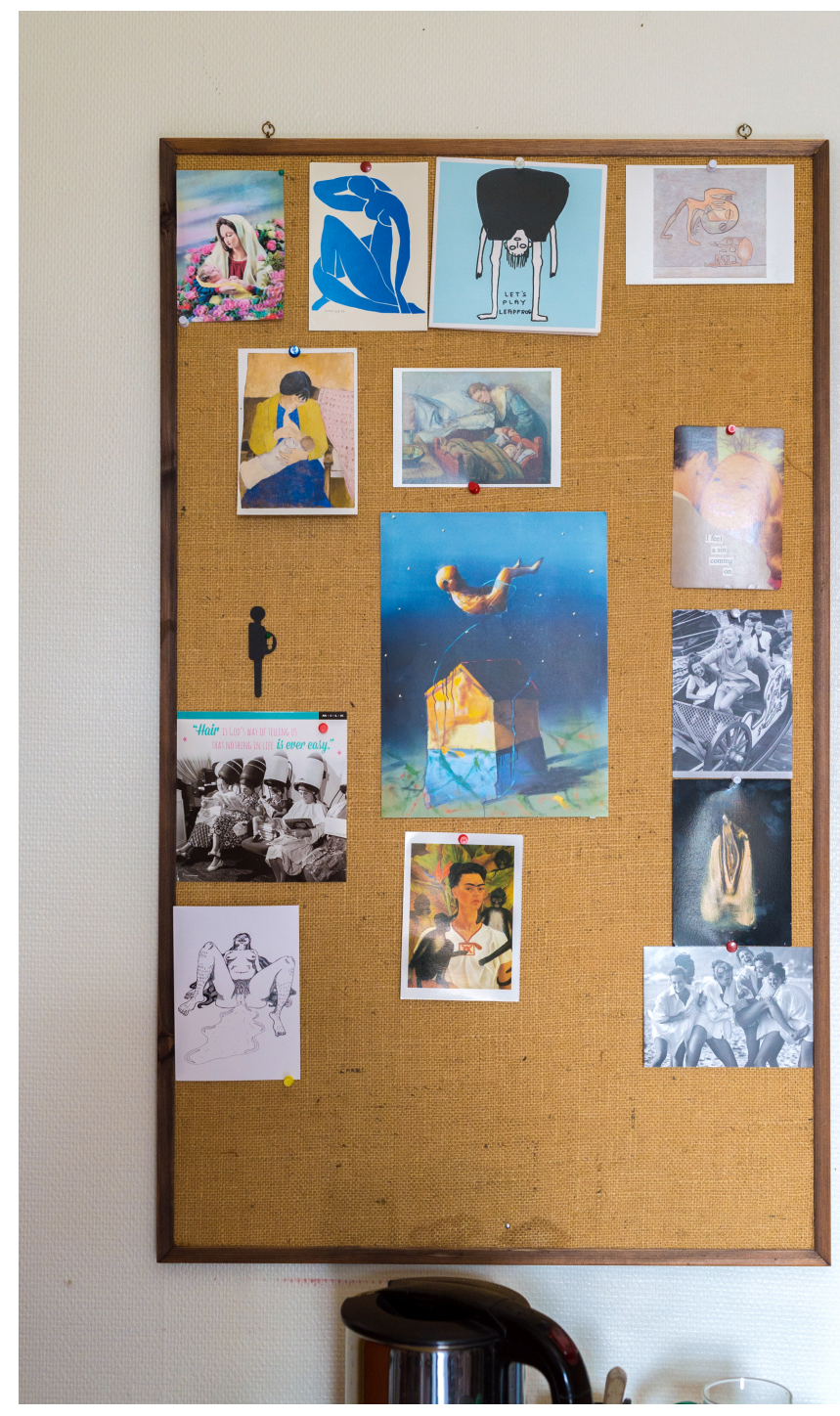

- Som overlege har jeg ansvaret for å være spesialisten med oppdatert kunnskap. Samtidig driver jeg med undervisning, forskning, formidling og foreningsarbeid. Det gjør jeg fordi jeg er engasjert.

Hun mener det er typisk for en norsk overlege å gjøre veldig mye arbeid basert på rent engasjement, at det er slikt vitenskapsbasert dugnadsarbeid som holder kvaliteten oppe på de faglige veilederne til blant annet Norsk gynekologisk forening.

- Det er verdifullt og bra at det er sånn, men det er viktig at våre arbeidsgivere og politikere skjønner verdien av denne innsatsen.

- Hva skal til for å bevare gnisten?

- Tid er alltid en faktor. Jeg har ikke en eneste dag i min hverdag som er satt av til den typen arbeid fra klinikkens side. Samtidig er det viktig for klinikken at jeg og mange andre deltar i denne typen fagdugnad.

\section{Alle har sin pris}

I Gynekologen har hun skrevet om konseptet hjerneflukt, «brain drain», i norsk kontekst tapet av fagfolk og kompetanse ut av en sektor eller et område etter at store ressurser har blitt brukt på utdanning og opplæring. 


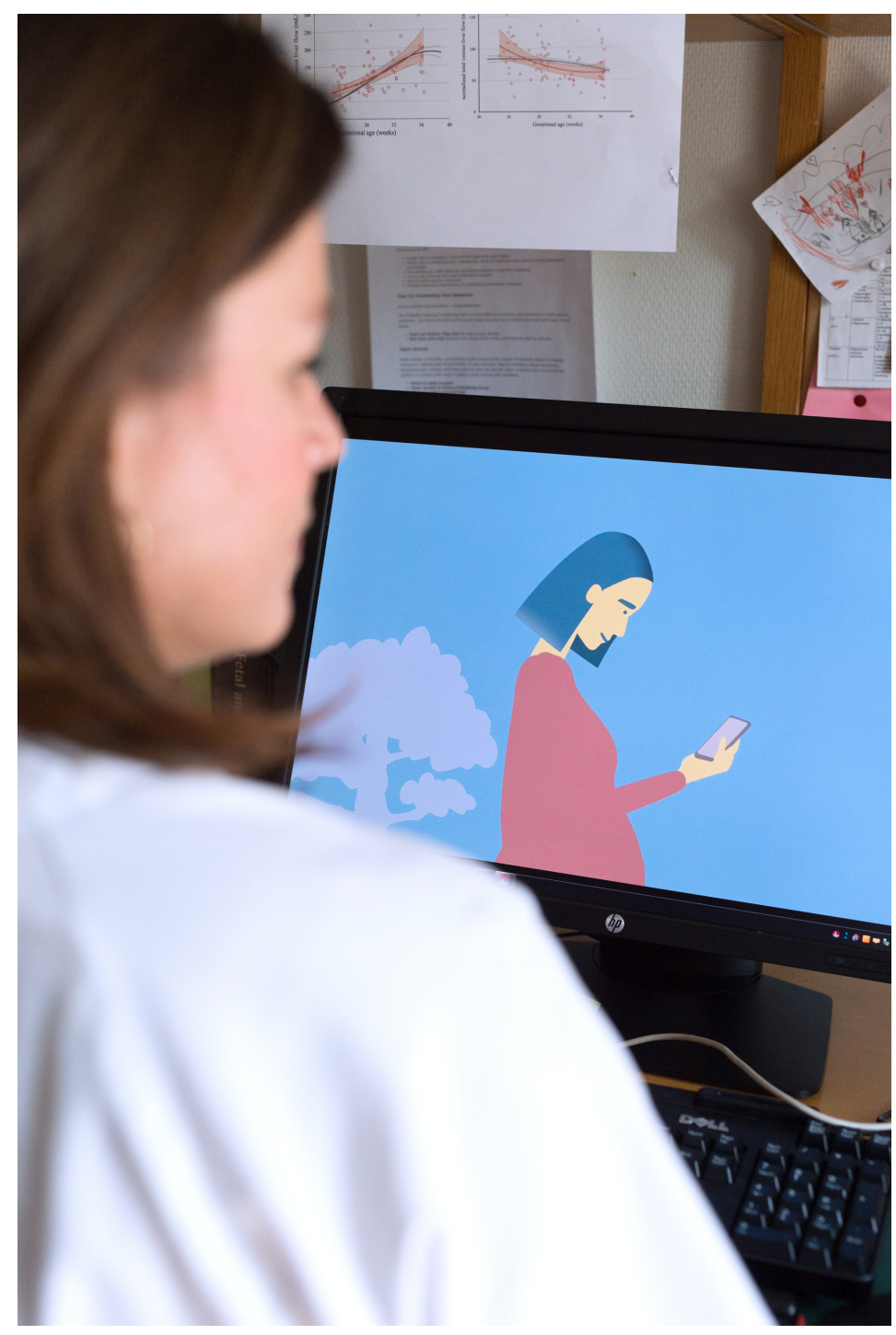

- Jeg fatter ikke at politikerne tør å satse på at private tjenester bygger seg mer opp. Mange er ikke helprivat finansiert av pasienten selv eller forsikringen, men er tjenestesteder som tilbyr operasjoner som det offentlige betaler for.

- Det kan godt hende det er mer effektivt, og kanskje er det billigere på papiret. Men det er ikke rart: Private tilbydere driver ikke undervisning, tar imot komplikasjoner eller har vaktberedskap døgnet rundt. Vi mangler allerede spesialister i Norge, da kan ikke disse lokkes ut til private foretak, mens vi sitter igjen med en offentlig stab tappet for overskudd og ressurser. Det henger ikke på greip.

Hun presiserer at hun ikke kritiserer samtlige helsepolitikere eller det private i seg selv.

- Men det offentlige trenger ikke selv å lage et parallelt marked for det. Vi har alle vår pris. Hvis jeg får et tilbud fra en klinikk som gir betydelig bedre lønn og er lite belastende i mitt privatliv, vil det alltid være et balansepunkt - også for en som er engasjert og elsker jobben sin. Jeg forstår ikke at de tør å tyne oss så mye som de gjør på offentlige sykehus.

\section{Landskap i endring}

Lund triller den blanke elsykkelen ved siden av seg opp den bratte og smale Møllendalsbakken. Gjennom parken og kirkegården er det stille. Noen mennesker er på vei til eller fra, noen tar en hvil ved steinen som bærer navnet til deres kjære. Inne på gårdsplassen i Jonas Lies vei står en dominerende og ærverdig gammel bygning, litt som slottet på Karl Johan. En ekte institusjon i mur, med store skarpt avkantede bokstaver på veggen. Kvinneklinikken. Nærmest vegg i vegg ligger Årstad kirke, og livets sirkel føles arkitektonisk velformulert. På Kvinneklinikken tar 6 oo ansatte seg av kvinnehelse i alle livets faser. Her ser 5 ooo nye mennesker dagens lys hvert år. 


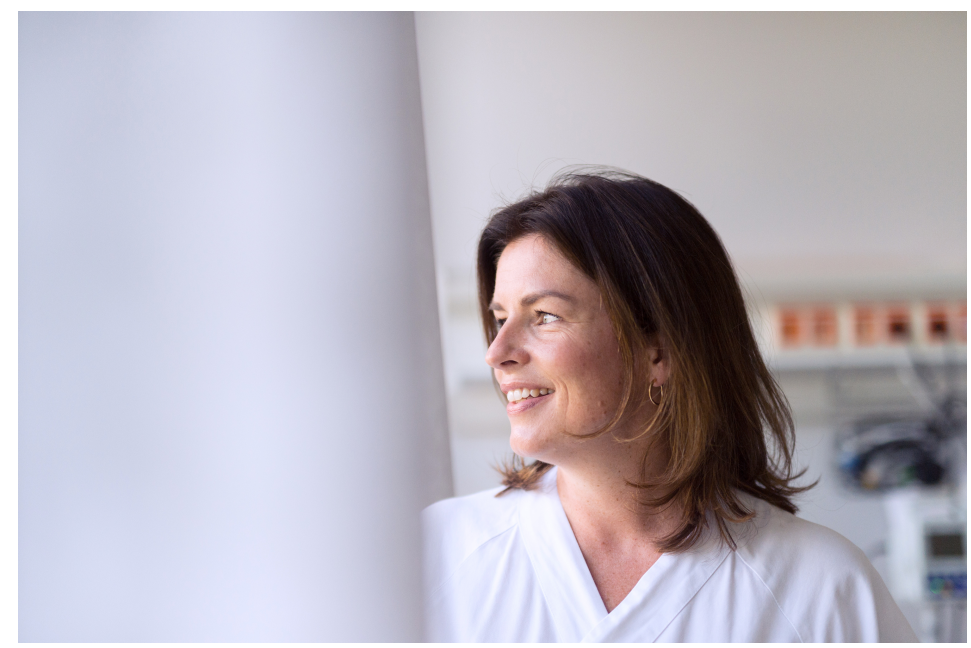

J.C. Dahl er utstilt på KODE 2 i sentrum, med sine detaljerte malerier av skipsforlis, mektige fjell og store daler, vill og urokkelig natur. På den ene veggen i galleriet henger flere års gjentatte motiver av Bergen tidlig på 18oo-tallet, sett fra Møllendal. Den gang var det landlig, Lungegårdsvannet hvilte mot grønne gresskanter. Fra høyden hvor Kvinneklinikken ligger, ser vi nær samme motiv som Dahl en gang så. Men fargene og strukturen er endret. I sør er det store veibruer, den nye bybanen blir til langs vannkanten under Kalfaret, og innerst i Møllendal har det som var industriområde på 19oo-tallet nå blitt revitalisert. Her ligger kunsthøyskole, promenader, kafeer, innovasjon. Møllendal Fetevare, der vi møttes tidligere på dagen, blir en av de urbane sømmene som legger seg inn i områdets nye kjolefolder.

Endringer skjer. Og Kvinneklinikken står snart for tur.

- Når det bygges nytt barne- og ungdomssykehus, skal også Kvinneklinikken inn i de samme lokalene. Et glasshus, uten kvinneklinikk i navnet. Flyttingen skjer, men navnet må våre ledere få gjort noe med. Kvinneklinikken er en institusjon - og vi kan ikke miste identiteten vår, sier Lund.

\section{Fremtidens kunnskapsdeling}

På Lunds kontor henger det postkort på korktavlen: Frida Kahlo, en vulva, en tegning av en naken kvinne som ligger på rygg med hårete legger.

Her inne skal vi møte en av dagens hovedpersoner, Dina. Hun ble konseptuelt unnfanget av Agnethe Lund på et møte for noen år siden og har hatt sin utvikling i korridorer og over tastatur, i faglitteratursøk og i møte med pasientgrupper og ulike møtefora i årene som har fulgt. Fra hun ble klargjort for offentligheten har hun hatt jobben med å møte den som tar kontakt på nett med et profesjonelt, kunnskapsrikt og åpent smil.

- Sant, hun er kul?

Lund viser et bilde av chatboten på skjermen, og forteller videre mens hun klikker rundt på hjemmesiden.

- Hovedmålsetningen er å styrke pasientens kunnskap om egen helse, sier Lund.

Vi klikker oss inn i Dinas snakkeboble. Hun skal kunne svare på alle de spørsmålene du har om svangerskapsdiabetes når du står der med ananasen i hånden på butikken, eller når du blir usikker på hva du kan spise til frokost.

- Ideen har kokt ned til informasjonsdeling. Det er der vi er i dag. Svangerskapsdiabetes behandles av damene selv, og dette er en måte å hjelpe dem på.

Vi spør Dina «Kan jeg spise brød?» og trykker send. Til svar kommer det opp en film av en klinisk ernæringsfysiolog. I tillegg popper det opp forhåndsforslag til hva enn mer vi skulle lure på.

- Vi har ingen hemmeligheter. Det vi vet, kan pasientene få vite. Og her kan vi gi dem linker 


\section{Kvinnehelse}

Ved siden av hverdagsliv, vaktliv, debatter og innovasjon, har akademia sin plass i Lunds virke. Om ikke lenge fullfører hun sin ph.d.-avhandling.

- Jeg har jobbet med å forstå hvordan fosterets fysiologi, og spesielt venøs blodstrøm, påvirkes når mor har diabetes type 1. I dag har vi gode måter å følge dem som har redusert fostervekst eller svangerskapsforgiftning med avansert ultralyd. Men i svangerskap med diabetes mangler vi fortsatt gode verktøy for å oppdage de som har høyest risiko tidlig.

Fostertiden skal vi alle gjennomgå, og svangerskapet skal nær 50 \% av Norges kropper bære. For Lund underbygger samfunnets fellesskap rundt fødsel behovet for flere ressurser til kvinnehelse.

- Dersom svangerskapsomsorgen står høyt i kurs i Norge, gjenspeiles det ikke i ressurstilgangen. Det nytter ikke å si at klinikkene skal finne løsningene selv. Det er et stort politisk ansvar å fordele ressursene på en riktig måte. Jeg mener at kvinnehelse burde få mer.

- Hvorfor akkurat kvinnehelse?

- For meg er det viktig, fordi alle mine pasienter er kvinner. Men det handler om mye mer enn som så. Det handler om et likeverdig helsetilbud til menn og kvinner gjennom hele livsløpet.

Lund nevner hvordan tilstander som preeklampsi, hypertensjon og svangerskapsdiabetes er viktige stresstester som kan gi et varsko om senere hjerte- og karsykdom, kunnskap som ukontroversielt kunne vært brukt til å finne risikopasienter og gi dem forebyggende tiltak. Men det gjenstår å inkludere dette i retningslinjer og langtidsoppfølging av kvinner.

Til sist handler det om å være løsningsorientert. Chatboten Dina er for Lund bare starten.

- Etter hvert kan lignende konsepter rettes mot andre sårbare grupper. Det er mye spennende som skjer. Hvis noen vil gi leger ressurser til å løfte blikket, så kan vi garantert bidra til å løse viktige utfordringer.

Publisert: 10. desember 2018. Tidsskr Nor Legeforen. DOI: 10.4045/tidsskr.18.0684

(C) Tidsskrift for Den norske legeforening 2020. Lastet ned fra tidsskriftet.no 